\title{
Primary pancreatic-type acinar cell carcinoma of the jejunum with tumor thrombus extending into the mesenteric venous system: a case report and literature review
}

\author{
Kosei Takagi ${ }^{i^{*}}$ (D), Takahito Yagi', Takehiro Tanaka², Yuzo Umeda', Ryuichi Yoshida', Daisuke Nobuoka',
} Takashi Kuise ${ }^{1}$ and Toshiyoshi Fujiwara'

\begin{abstract}
Background: Although ectopic pancreatic tissue is common in the upper gastrointestinal tract, the incidence of ectopic pancreatic tissue in the jejunum is low, and malignant transformation in ectopic pancreatic tissue is rare. Furthermore, pancreatic-type acinar cell carcinoma (ACC) developing in the jejunum and ACC accompanied by tumor thrombus are extremely rare.

Case presentation: A 78-year-old-woman presented with melena. Abdominal computed tomography images and endoscopic examination revealed a submucosal jejunal mass with tumor thrombus extending into a jejunal vein. The patient underwent a curative resection combined with a partial jejunectomy and partial pancreatectomy. Histopathological examination of the resected tissue showed tumor cells with a homogeneous acinar architecture identical to pancreatic-type ACC and tumor thrombus. Postoperatively, she was followed for 10 months and had no recurrence.

Conclusion: We present an extremely rare case of pancreatic-type ACC in the jejunum with extensive tumor thrombus invading into the mesenteric venous system. This type of cancer has not been reported previously but should be considered in the differential diagnosis of a jejunal mass.
\end{abstract}

Keywords: Acinar cell carcinoma, Jejunum, Ectopic pancreas, Tumor thrombus

\section{Background}

Ectopic pancreatic tissue is most frequently found in the upper gastrointestinal tract, and malignant transformation of ectopic pancreatic tissue is rare. In the English literature, approximately 30 cases of adenocarcinoma arising from ectopic pancreatic tissue have been reported, and most occurred in the upper gastrointestinal tract $[1,2]$. Only seven cases of adenocarcinoma arising from ectopic pancreatic tissue in the jejunum have been reported [3].

\footnotetext{
* Correspondence: kotakagi15@gmail.com

${ }^{1}$ Department of Gastroenterological Surgery, Okayama University Graduate

School of Medicine, Dentistry and Pharmaceutical Sciences, 2-5-1

Shikata-cho, Kita-ku, Okayama 700-8558, Japan

Full list of author information is available at the end of the article
}

Acinar cell carcinoma (ACC) is a rare malignant tumor that accounts for $1-2 \%$ of all exocrine pancreatic neoplasms and usually arises in the pancreatic parenchyma [4]. ACC derived from ectopic pancreatic tissue is very rare, with only 12 previous reports [1, 2, 5-14]. Among these reports, only one described ACC in jejunal pancreatic heterotopia [14]. Furthermore, ACC accompanied by tumor thrombus is very rare. In the English literature, there have been only two reports of ACC with portal vein tumor thrombus $[15,16]$.

We herein report an extremely rare case of pancreatictype ACC presenting as a submucosal jejunal tumor accompanied by tumor thrombus and review the previously reported cases of heterotopic ACC. 


\section{Case presentation}

A 78-year-old woman was admitted to another hospital complaining of melena and transferred to our facility for further examination. Her physical examination was unremarkable. The laboratory values were as follows: white blood count, 4220 cells/ $\mu \mathrm{L}$; hemoglobin level, $12.4 \mathrm{~g} / \mathrm{dL}$;
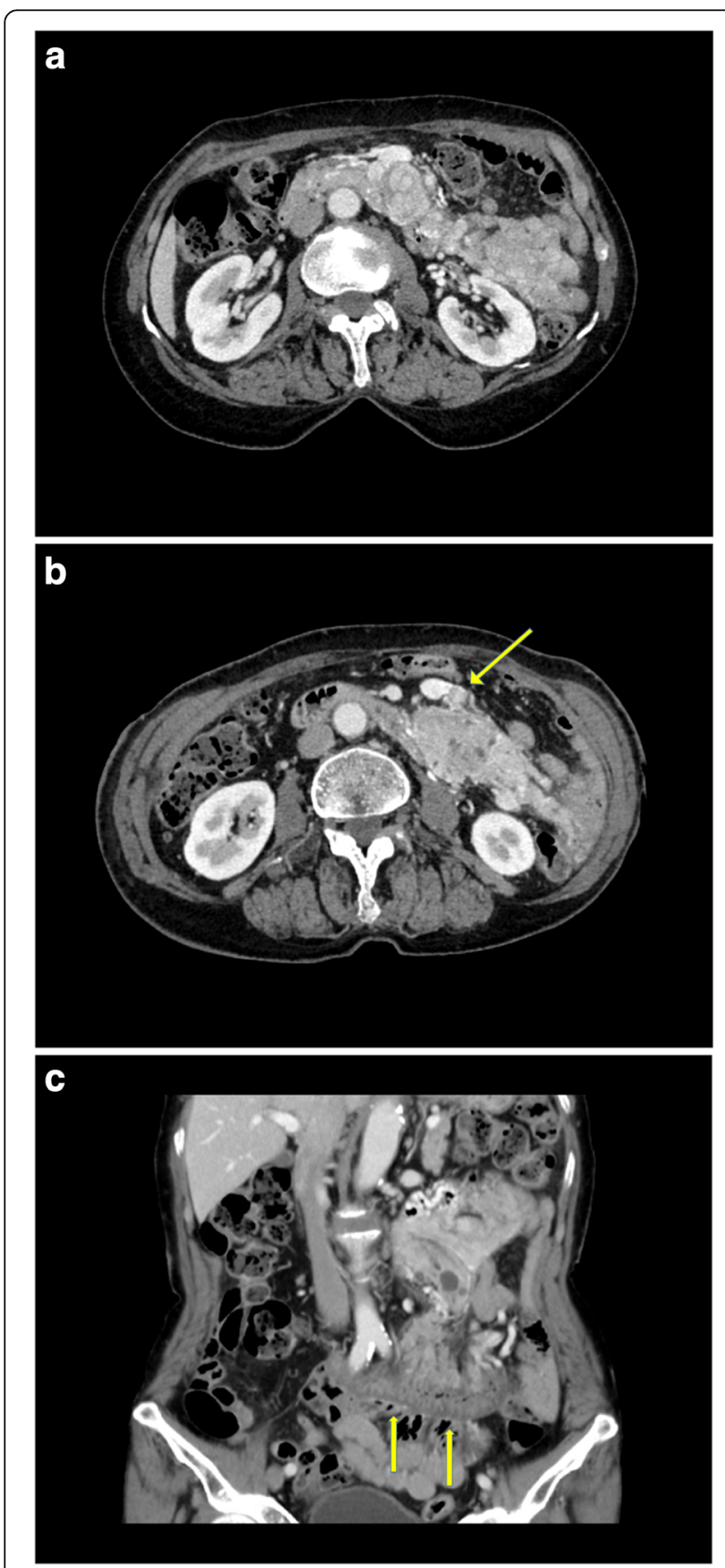

Fig. 1 Preoperative computed tomography scans: a. An $8.5 \times 4.0 \mathrm{~cm}$ exophytic submucosal tumor located in the jejunum. The posterior aspect of the superior mesenteric vein is compressed by the tumor, and the tumor extends to the uncinate process of the pancreas; b. The tumor thrombus invades the first jejunal vein (arrow); c. The jejunal mesentery shows significant thickening (arrow) platelet count, $16.4 \times 10^{4}$ cells $/ \mu \mathrm{L}$; aspartate transaminase, $25 \mathrm{IU} / \mathrm{L}$; alanine aminotransferase, $16 \mathrm{IU} / \mathrm{L}$; total bilirubin, $0.8 \mathrm{mg} / \mathrm{dL}$; albumin, $3.6 \mathrm{~g} / \mathrm{dL}$; and creatinine, $0.48 \mathrm{mg} / \mathrm{dL}$. Tumor markers (carcinoembryonic antigen, carbohydrate antigen 19-9, s-pancreas-1 antigen, and Duke pancreatic monoclonal antigen type 2) were within normal limits.

Abdominal computed tomography scans revealed an $8.5 \times 4.0 \mathrm{~cm}$ exophytic submucosal tumor in the jejunum (Fig. 1a). The tumor extended to the uncinate process of the pancreas and compressed the posterior aspect of the superior mesenteric vein. The first jejunal vein was thrombosed, and we suspected a tumor thrombus. Tumor thrombus was not identified in the superior mesenteric vein (Fig. 1b). We also observed significant thickening of the jejunal mesentery, but no distant metastasis was found (Fig. 1c).

Double-balloon enteroscopy showed an approximately $3 \mathrm{~cm}$ submucosal tumor with central ulceration in the jejunum (Fig. 2a). Endoscopic biopsy revealed a poorly
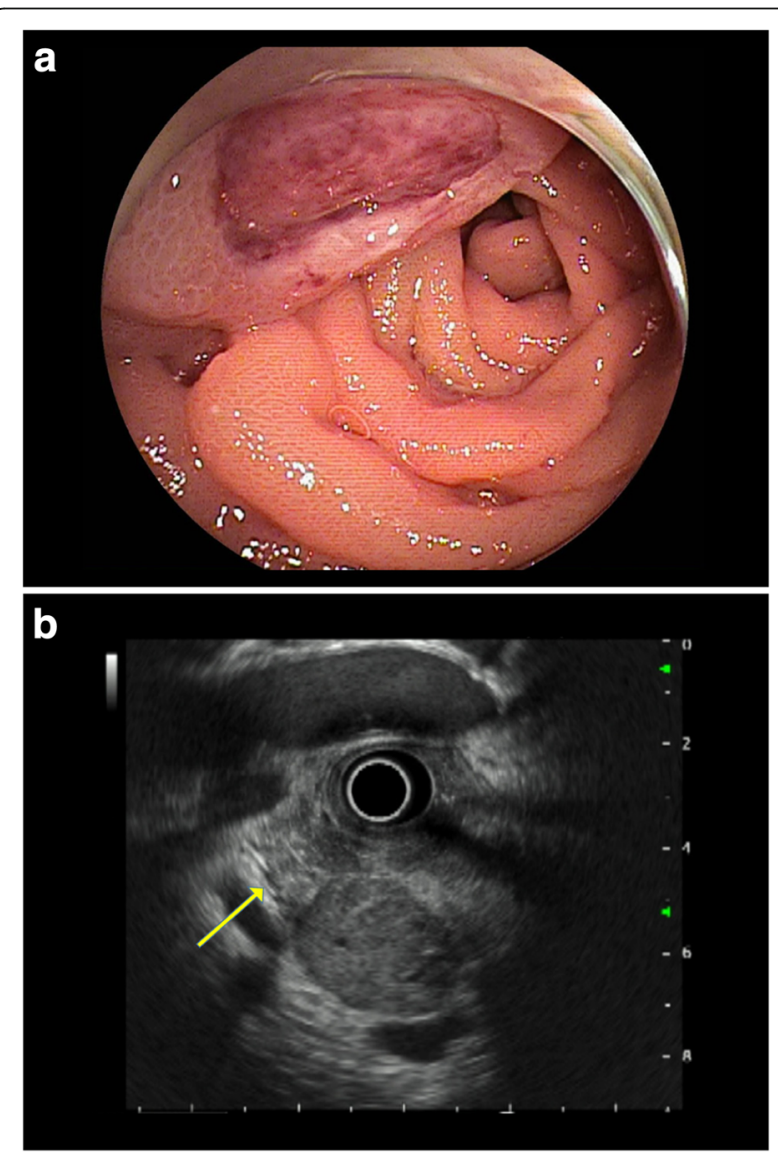

Fig. 2 Endoscopic examination: a. Double-balloon enteroscopy reveals a centrally ulcerated submucosal jejunal lesion measuring approximately $3 \mathrm{~cm}$; b. Endoscopic ultrasonography shows a submucosal tumor touching the uncinate process of the pancreas, suggesting the possibility of pancreatic infiltration (arrow, pancreas) 
differentiated adenocarcinoma. Endoscopic ultrasonography showed a submucosal jejunal tumor which touched the uncinate process of the pancreas and suggested possible pancreatic infiltration (Fig. 2b).

Our preoperative diagnosis was a jejunal adenocarcinoma. Although there was tumor thrombus in the mesenteric venous system and the possibility of pancreatic invasion, we considered the tumor resectable.

At surgery, there was neither peritoneal dissemination nor liver metastasis. The tumor was located mainly in the mesentery of the upper jejunum. No invasion of the superior mesenteric artery or vein was found. We did not observe invasion of the pancreatic uncinate process grossly, but we resected it. Accordingly, the patient underwent a curative resection combined with a partial jejunectomy (approximately $50 \mathrm{~cm}$ of the jejunum) and a partial pancreatectomy (uncinate process).

The gross examination revealed an $8.5 \mathrm{~cm}$, soft, circumscribed, yellowish-white, submucosal mass in the jejunum (Fig. 3a). Histologically, the tumor showed an acinar and solid growth pattern (Fig. 3b). Marked vascular invasion was observed, and the tumor thrombus extended into the first jejunal vein (Fig. 3c). The tumor was confined to the jejunal wall without pancreatic parenchymal invasion (Fig. 3d). Immunohistochemically, the tumor cells were positive for trypsin and negative for chromogranin A, synaptophysin, and CD56 (Figs. 3e, f, $\mathrm{g}$, and $\mathrm{h}$ ). The resected margins were free of tumor cells. Although residual ectopic pancreas was not identified, the tumor was diagnosed as pancreatic-type ACC of the jejunum based on the architectural patterns of ACC and immunohistochemical findings.

The postoperative course was uneventful. The patient received adjuvant chemotherapy with S-1 (TS-1; Taiho Pharmaceutical, Tokyo, Japan) after the curative resection. She was alive and without recurrence at her last follow-up visit 10 months postoperatively.

\section{Discussion and conclusions}

To the best of our knowledge, this is the first report of pancreatic-type ACC in the jejunum accompanied by tumor thrombus in the mesenteric venous system. This report highlights the clinicopathological findings of an extremely rare case and reviews the features of previously reported cases of heterotopic ACC.

There have been only 13 cases, including our case, reporting heterotopic ACC in a digestive organ (Table $1)$. The cases included seven women and six men with a mean age of 61.8 years. Heterotopic ACC was most frequently found in the upper gastrointestinal tract. The average tumor size was relatively large $(4.5 \mathrm{~cm})$. Interestingly, no case was preoperatively diagnosed as ACC. Indeed, five cases were diagnosed as poorly differentiated adenocarcinoma by biopsy, and other tumor types were suspected in four cases. ACCs usually develop submucosally, so preoperative diagnosis by histological examination might be difficult. Furthermore, the histological examination of the resected specimen revealed ectopic pancreatic tissue in only two cases.

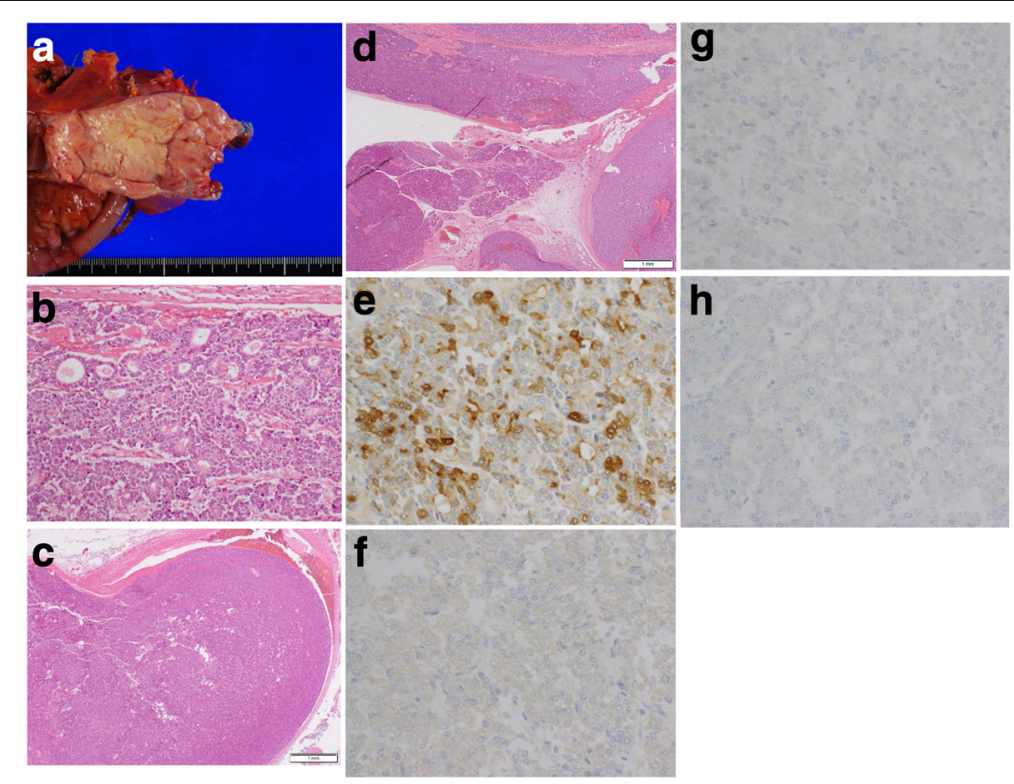

Fig. 3 Pathological examination of the jejunal tumor: a. Gross examination shows an $8.5 \mathrm{~cm}$, soft, circumscribed, yellowish-white, submucosal mass in the jejunum; b. Microscopic examination reveals acinar and solid architectural patterns; c. Marked vascular invasion, including tumor thrombus, extends into the first jejunal vein; $\mathbf{d}$. No invasion to the pancreatic parenchyma is identified; Immunohistochemically, the tumor cells are positive for trypsin (e) and negative for chromogranin A (f), synaptophysin $(\mathbf{g})$, and CD56 (h) 
Table 1 Demographic and clinicopathological features in reported cases of acinar cell carcinoma arising from heterotopic pancreas

\begin{tabular}{|c|c|c|c|c|c|c|c|c|c|c|}
\hline Reports & $\begin{array}{l}\mathrm{Age}^{\mathrm{a}} \\
/ \mathrm{Sex}\end{array}$ & Site & $\begin{array}{l}\text { Size } \\
(\mathrm{cm})\end{array}$ & $\begin{array}{l}\text { Preoperative } \\
\text { diagnosis }\end{array}$ & Metastasis & Tumor characteristics & Treatment & $\begin{array}{l}\text { Adjuvant } \\
\text { chemo }\end{array}$ & EPT & Outcome \\
\hline Sun et al. 2004 [5] & $86 / F$ & Stomach & 5.0 & PDA & None & Exophytic, ulcerated & $\begin{array}{l}\text { Partial } \\
\text { gastrectomy }\end{array}$ & NM & A & NM \\
\hline $\begin{array}{l}\text { Mizuno et al. } 2007 \\
\text { [6] }\end{array}$ & $\begin{array}{l}73 / \\
M\end{array}$ & Stomach & 7.6 & GIST/L & LN & Submucosal & PD & NM & A & $\begin{array}{l}11 \text { months alive, } \\
\text { liver metastasis } \\
\text { at } 7 \text { months }\end{array}$ \\
\hline $\begin{array}{l}\text { Ambrosini-Spaltro } \\
\text { et al. } 2009 \text { [7] }\end{array}$ & $\begin{array}{l}52 / \\
M\end{array}$ & Stomach & 4.0 & PDA & None & Ulcerated & $\begin{array}{l}\text { Subtotal } \\
\text { gastrectomy }\end{array}$ & NM & $\mathrm{P}$ & NM \\
\hline $\begin{array}{l}\text { Coyne et al. } 2012 \\
\text { [8] }\end{array}$ & $77 / F$ & Stomach & 4.5 & PDA & None & $\begin{array}{l}\text { Ulcerated, } \\
\text { submucosal }\end{array}$ & $\begin{array}{l}\text { Partial } \\
\text { gastrectomy }\end{array}$ & NM & A & NM \\
\hline $\begin{array}{l}\text { Yonenaga et al. } \\
2016 \text { [2] }\end{array}$ & $\begin{array}{l}63 / \\
M\end{array}$ & Stomach & 6.5 & PDA & Liver & $\begin{array}{l}\text { Borrmann type-2 } \\
\text { lesion }\end{array}$ & Chemo & None & A & $\begin{array}{l}5 \text { month died, } \\
\text { sepsis }\end{array}$ \\
\hline Kim et al. 2017 [9] & $\begin{array}{l}54 / \\
M\end{array}$ & Stomach & 2.7 & GIST/L & None & Submucosal & $\begin{array}{l}\text { Wedge } \\
\text { resection }\end{array}$ & None & A & $\begin{array}{l}33 \text { months } \\
\text { alive, NR }\end{array}$ \\
\hline $\begin{array}{l}\text { Bookman } 1932 \\
{[10]}\end{array}$ & $28 / F$ & Duodenum & NM & Benign $^{b}$ & None & NM & Partial resection & NM & A & NM \\
\hline $\begin{array}{l}\text { Jahromi et al. } 2013 \\
\text { [1] }\end{array}$ & $\begin{array}{l}58 / \\
M\end{array}$ & Duodenum & 2.7 & NM & None & Submucosal & Partial resection & Cap + Oxal & A & $\begin{array}{l}18 \text { months } \\
\text { alive, NR }\end{array}$ \\
\hline $\begin{array}{l}\text { Kawakami et al. } \\
2007 \text { [11] }\end{array}$ & $65 / F$ & AoV & 1.2 & NM & None & Exophytic & PD & NM & A & $\begin{array}{l}19 \text { months } \\
\text { alive, NR }\end{array}$ \\
\hline $\begin{array}{l}\text { Hervieu et al. } 2008 \\
\text { [12] }\end{array}$ & $35 / F$ & Liver & 4.0 & $\mathrm{HCC}$ & None & Well-limited & Hepatectomy & None & A & 6 years alive, NR \\
\hline $\begin{array}{l}\text { Chiaravalli et al. } \\
2009 \text { [13] }\end{array}$ & $65 / F$ & Colon & 4.0 & NM & LN & Ulcerated & Partial resection & NM & A & $\begin{array}{l}24 \text { months died, } \\
\text { bone metastasis } \\
\text { at } 18 \text { months }\end{array}$ \\
\hline $\begin{array}{l}\text { Makhlouf et al. } \\
1999 \text { [14] }\end{array}$ & $\begin{array}{l}71 / \\
M\end{array}$ & Jejunum & 3.5 & NM & None & Ulcerated & Partial resection & NM & $P$ & $\begin{array}{l}1 \text { year alive, liver } \\
\text { metastasis at } \\
1 \text { year }\end{array}$ \\
\hline Our case & $76 / F$ & Jejunum & 8.5 & PDA & None & $\begin{array}{l}\text { Exophytic, ulcerated, } \\
\text { submucosal, mass } \\
\text { with tumor thrombus }\end{array}$ & $\begin{array}{l}\text { Partial resection } \\
\text { with partial } \\
\text { pancreatectomy }\end{array}$ & S-1 & A & $\begin{array}{l}10 \text { months } \\
\text { alive, NR }\end{array}$ \\
\hline
\end{tabular}

$F$ female, $M$ male, $P$ present, $A$ absent, $P D A$ poorly differentiated adenocarcinoma, NM not mentioned, GIST/L gastrointestinal stromal tumor or lymphoma, $H C C$ hepatocellular carcinoma, AoV ampulla of Vater, Cap + Oxal Capecitabine + Oxaliplatin, PD pancreaticoduodenectomy, Chemo chemotherapy, EPT ectopic pancreatic tissue, $N R$ no recurrence, $L N$ lymph node

${ }^{\text {a }}$ Reported in years; ${ }^{\text {b } B e n i g n ~ t u m o r ~ s u c h ~ a s ~ a ~ p o l y p ~}$

Ectopic pancreatic tissue is found in $0.5-13.7 \%$ of laparotomy and autopsy cases and is usually located in the upper gastrointestinal tract [3]. The pathological classification of ectopic pancreas was diagnosed by the Heinrich classification [17]. Malignant transformation of ectopic pancreas tissue most frequently occurs in the upper digestive organs, and the reported incidence ranges from $0.7-1.8 \%$ [3]. The following three criteria have been proposed for ectopic pancreas carcinoma: the tumor must be found within or near the ectopic pancreas, a transition between pancreatic structures and carcinoma must be observed, and the non-neoplastic pancreatic tissue must comprise fully developed acini and ductal structures [18]. However, similar to most previous cases, in our case, no ectopic pancreas tissue was identified (Table 1). It has been proposed that a carcinoma arising from ectopic pancreas destroys the primary benign lesion [14].
ACC is typically relatively circumscribed and large with extensive hemorrhage and necrosis [19]. The characteristic microscopic architectural patterns are the acinar pattern, with neoplastic cells arranged in small acinar units, and solid pattern, with solid nests of neoplastic cells lacking luminal formations [20]. In the histopathologic diagnosis of ACC, an immunohistochemical evaluation of pancreatic exocrine enzymes is helpful; both trypsin and chymotrypsin are positive in more than $95 \%$ cases [20]. Furthermore, neuroendocrine markers such as chromogranin A, synaptophysin, and CD56 should be assessed when ACC is in the differential diagnosis [9]. In our case, the tumor showed both acinar and solid growth patterns, trypsin-positivity, and neuroendocrine marker-negativity. Therefore, we diagnosed a pure pancreatic-type ACC of the jejunum.

Although ACC has been considered to have a poor prognosis, the surgical resection and 5-year survival 
rates after resection have been reported as 76.5 and $43.9 \%$, respectively, in a nationwide survey performed in Japan [21]. Furthermore, patients with ACC had a significantly better prognosis than those with pancreatic ductal adenocarcinoma [22]. Aggressive surgical resection with negative margins is also associated with longer survival [23]. However, the prognosis of heterotopic ACC remains unclear because of the limited number of reported cases.

Pancreatic cancers frequently invade the portal venous system leading to extrinsic portal vein obstruction. However, intrinsic venous obstruction by tumor thrombus, while a common occurrence in hepatocellular carcinoma, rarely occurs in pancreatic cancer [16]. Indeed, there have been only a few cases of pancreatic cancer with portal vein tumor thrombus, including two cases of ACC accompanied by tumor thrombus $[15,16]$. Furthermore, distinguishing tumor thrombus from a blood clot is very important, because it is well recognized that a tumor thrombus involving the mesenteric venous system is associated with liver metastases. The treatment strategy will also be affected by the preoperative evaluation. In our case, although tumor thrombus was present in the first jejunal vein accompanied by significant mesenteric thickening, we considered the tumor resectable because there were no distant metastases.

The efficacy of neoadjuvant or adjuvant chemotherapy for ACC arising in ectopic pancreatic tissue is still unknown. In patients with unresectable ACC, fluorouracilbased chemotherapy should be considered a neoadjuvant or palliative treatment [24]. However, in the previous 12 reports of heterotopic ACC, only one patient received adjuvant treatment with capecitabine and oxaliplatin after curative resection (Table 1).

In our case, the patient had a high risk of recurrence because of extensive tumor thrombus. Therefore, administered S-1 as adjuvant chemotherapy according to the treatment for pancreatic cancer after curative resection [25]. The patient continued chemotherapy without severe adverse effects or recurrence postoperatively. Future studies are required to assess heterotopic ACC's sensitivity to chemotherapy and long-term treatment outcomes.

In conclusion, we have presented an extremely rare case of pancreatic-type ACC arising in the jejunum with extensive tumor thrombus into the mesenteric venous system. Although it is difficult to diagnose heterotopic ACC because of its rarity, such lesions may develop in the gastrointestinal tracts as submucosal tumors, sometimes accompanied by tumor thrombus. Curative resection in these cases could be associated with increased survival.

\section{Abbreviation}

ACC: Acinar cell carcinoma

Acknowledgements

We would like to thank Editage (www.editage.jp) for English language editing.
Funding

The authors declare that they received no funding for this case report.

Availability of data and materials

All data generated or analyzed during this study are included in this published article.

\section{Authors' contributions}

$K T$ and $T T$ wrote the draft. KT, TY, YU, RY, DN, and TK performed the surgery and perioperative care. $\Pi$ contributed to the pathological diagnosis. TY and TF revised and finalized the draft. All authors read and approved the final manuscript.

\section{Author's information}

Not applicable.

\section{Ethics approval and consent to participate}

This study was approved by the Ethics Committee of the Okayama University Graduate School of Medicine, Dentistry and Pharmaceutical Sciences and Okayama University Hospital.

\section{Consent for publication}

Written informed consent was obtained from the patient for publication of this case report and any accompanying images.

Competing interests

The authors declare that they have no competing interests.

\section{Publisher's Note}

Springer Nature remains neutral with regard to jurisdictional claims in published maps and institutional affiliations.

\section{Author details}

${ }^{1}$ Department of Gastroenterological Surgery, Okayama University Graduate School of Medicine, Dentistry and Pharmaceutical Sciences, 2-5-1

Shikata-cho, Kita-ku, Okayama 700-8558, Japan. ${ }^{2}$ Department of Diagnostic Pathology, Okayama University Hospital, 2-5-1 Shikata-cho, Kita-ku, Okayama 700-8558, Japan.

Received: 18 March 2017 Accepted: 26 June 2017

Published online: 29 June 2017

\section{References}

1. Hamidian Jahromi A, Shokouh-Amiri H, Wellman G, Hobley J, Veluvolu A, Zibari GB. Acinar cell carcinoma presenting as a duodenal mass: review of the literature and a case report. J La State Med Soc. 2013;165:20-3. 25

2. Yonenaga $Y$, Kurosawa M, Mise M, Yamagishi M, Higashide S. Pancreatic-type Acinar cell carcinoma of the stomach included in multiple primary carcinomas. Anticancer Res. 2016:36:2855-64.

3. Yamaoka $Y$, Yamaguchi T, Kinugasa $Y$, Shiomi A, Kagawa H, Yamakawa $Y$, et al. Adenocarcinoma arising from jejunal ectopic pancreas mimicking peritoneal metastasis from colon cancer: a case report and literature review. Surg Case Rep. 2015;1:114

4. Ordóñez NG. Pancreatic acinar cell carcinoma. Adv Anat Pathol. 2001;8:144-59.

5. Sun $Y$, Wasserman $P G$. Acinar cell carcinoma arising in the stomach: a case report with literature review. Hum Pathol. 2004;35:263-5.

6. Mizuno $Y$, Sumi $Y$, Nachi S, Ito $Y$, Marui T, Saji S, et al. Acinar cell carcinoma arising from an ectopic pancreas. Surg Today. 2007;37:704-7.

7. Ambrosini-Spaltro A, Potì O, De Palma M, Filotico M. Pancreatic-type acinar cell carcinoma of the stomach beneath a focus of pancreatic metaplasia of the gastric mucosa. Hum Pathol. 2009;40:746-9.

8. Coyne JD. Pure pancreatic-type acinar cell carcinoma of the stomach: a case report. Int J Surg Pathol. 2012;20:71-3.

9. Kim KM, Kim CY, Hong SM, Jang KY. A primary pure pancreatic-type acinar cell carcinoma of the stomach: a case report. Diagn Pathol. 2017;12:10.

10. Bookman MR. Carcinoma in the Duodenum: originating from aberrant pancreatic cells. Ann Surg. 1932;95:464-7.

11. Kawakami H, Kuwatani M, Onodera M, Hirano S, Kondo S, Nakanishi Y, et al. Primary acinar cell carcinoma of the ampulla of Vater. J Gastroenterol. 2007:42:694-7. 
12. Hervieu V, Lombard-Bohas C, Dumortier J, Boillot O, Scoazec JY. Primary acinar cell carcinoma of the liver. Virchows Arch. 2008;452:337-41.

13. Chiaravalli AM, Finzi G, Bertolini V, La Rosa S, Capella C. Colonic carcinoma with a pancreatic acinar cell differentiation. A case report. Virchows Arch. 2009;455:527-31.

14. Makhlouf HR, Almeida JL, Sobin LH. Carcinoma in jejunal pancreatic heterotopia. Arch Pathol Lab Med. 1999;123:707-11.

15. Ueda T, Ku Y, Kanamaru T, Hasegawa Y, Kuroda Y, Saitoh Y. Resected acinar cell carcinoma of the pancreas with tumor thrombus extending into the main portal vein: report of a case. Surg Today. 1996;26:357-60.

16. Igarashi H, Shinozaki S, Mukada T. A case of acinar cell carcinoma of the pancreas that formed extensive tumor thrombus of the portal vein. Clin J Gastroenterol. 2009;2:96-102.

17. Saad RS, Essig DL, Silverman JF, Liu Y. Diagnostic utility of CDX-2 expression in separating metastatic gastrointestinal adenocarcinoma from other metastatic adenocarcinoma in fine-needle aspiration cytology using cell blocks. Cancer. 2004;102:168-73.

18. Guillou L, Nordback P, Gerber C, Schneider RP. Ductal adenocarcinoma arising in a heterotopic pancreas situated in a hiatal hernia. Arch Pathol Lab Med. 1994;118:568-71.

19. Klimstra DS, Heffess CS, Oertel JE, Rosai J. Acinar cell carcinoma of the pancreas. A clinicopathologic study of 28 cases. Am J Surg Pathol. 1992;16:815-37.

20. Bosman FT, Carneiro F, Hruban RH, Theise ND. WHO classification of tumours of the digestive system. In: Klimstra DS, Hruban RH, Kloppel G, Morohoshi T, Ohike N, editors. Acinar cell neoplasms of the pancreas. Lyon: IARC Press; 2010. p. 314-8.

21. Kitagami H, Kondo S, Hirano S, Kawakami H, Egawa S, Tanaka M. Acinar cell carcinoma of the pancreas: clinical analysis of 115 patients from pancreatic cancer registry of Japan pancreas society. Pancreas. 2007;35:42-6.

22. Wisnoski NC, Townsend CM Jr, Nealon WH, Freeman JL, Riall TS. 672 patients with acinar cell carcinoma of the pancreas: a population-based comparison to pancreatic adenocarcinoma. Surgery. 2008;144:141-8.

23. Schmidt CM, Matos JM, Bentrem DJ, Talamonti MS, Lillemoe KD, Bilimoria KY Acinar cell carcinoma of the pancreas in the United States: prognostic factors and comparison to ductal adenocarcinoma. J Gastrointest Surg. 2008;12:2078-86.

24. Distler M, Rückert F, Dittert DD, Stroszczynski C, Dobrowolski F, Kersting S, et al. Curative resection of a primarily unresectable acinar cell carcinoma of the pancreas after chemotherapy. World J Surg Oncol. 2009;7:22.

25. Sudo K, Nakamura K, Yamaguchi T. S-1 in the treatment of pancreatic cancer. World J Gastroenterol. 2014;20:15110-8.

\section{Submit your next manuscript to BioMed Central and we will help you at every step:}

- We accept pre-submission inquiries

- Our selector tool helps you to find the most relevant journal

- We provide round the clock customer support

- Convenient online submission

- Thorough peer review

- Inclusion in PubMed and all major indexing services

- Maximum visibility for your research

Submit your manuscript at www.biomedcentral.com/submit

CBiomed Central 